\title{
SELF-MONITORING CONTROVERSIES
}

\author{
Irena Gailienè \\ SMC "Scientia Educologica", Lithuania \\ E-mail: gailiene@splius.It
}

Nobody will out-argue the fact, that all of us are in social situations each day. Even being alone, we think over what impression we made on others, what we should do that the others valued us more favourably, that we were more attractive. Creation of good image and its preservation is very urgent in recent time period, when supply considerably exceeds demand in labour market, and a good impression directly affects job search, career success; when short-term interpersonal relations dominate, and communication, affiliation needs haven't died out yet, and, searching for new contacts, we want to be attractive, emotionally accepted, loveable. Much information, various instructions can be found, on how to create a good impression, how to present yourself to the employers, how to expose the best qualities of your personality in the presence of the surrounding people. However, still too little is written and spoken about one of the essential factors of personality attractiveness - self-monitoring, i.e., analysis, checking and correction of verbal and non-verbal information sent about you, about your behaviour, comparing it with social norms, behavioural standards, other people's reactions and expectations. Thus, it is not sufficient to master straightforwardly good image creation technique, because it is extremely important to perceive and to become aware of the others' reactions to our behaviour, to control oneself for social interactions to be effective and to ensure social situation's adequacy. For example, the sender of the information about himself can consider that he fascinated the surrounding people by his competence, humour or irreproachable appearance, whilst for the other people such demonstrated traits can not arouse any impression and even conversely - can cause rejection reactions. Therefore, wishing at least "not to fall out" from the social context, it is necessary to analyse information, received as a feedback, to develop self-monitoring competence.

Perhaps the first who analysed self-monitoring phenomena and processes in the personality in different aspects was Mark Snyder (1974). According to self-monitoring level the author distinguishes two categories of people: closely self-monitoring their behaviour and concentrated to others' reactions (high self-monitors) and poorly self-monitoring their behaviour, almost not paying attention to others' reactions (low self-monitors). M. Snyder developed a scale for fixing self-monitoring level (self-monitoring scale, 1980). Naturally, the questions arise: what behaviour and what personality traits are characteristic to high and low level self-monitors; how this affects working and interpersonal relations; what motives can inspire high and low self- monitoring; what attention should be paid to, seeking optimal self-monitoring level?

High self-monitoring is expressed by three main components: a willingness to be the centre of attention, sensitivity to others' reactions, ability and willingness to regulate one's behaviour and to arouse positive reactions of the others (Greenberg, Baron, 1990). Such type of people tend to adapt to different people's expectations in different situations, different surroundings. They are able to very quickly change their behaviour, attitudes, standpoint and emotions according to social "order". Self-evaluation of such category of people is based on social standards. They easily adapt to any surroundings. On the one hand, high self-monitors' flexibility and adaptivity can be evaluated as positive traits, however behavioural inconsistency, "mask" changing cause distrust of the surrounding people and a wish to separate from them in the time being. Losing self, authenticity, they become social chameleons. It is thought, that high self-monitors can be good leaders, however suffice it to imagine a leader, not having his own opinion, under pressure of social surroundings, betraying his own values, beliefs and so on, in order to win other people's favour. Having such type of leaders, it is complicated to hope for an outbreak of new ideas, organization progress in general. 
Low self-monitoring people show very little concern what impression they make on others. Their behaviour is consistent, comparing to what they are in personal area and how they behave in public. Attitudes, beliefs are steady, because they depend on internal information, but not on social expectations and orders. Self-evaluation is also based on internal standards. The steadiness and authenticity of these people arouse trust and favour of the surrounding people, because being self endures time tests. However, little attention to others' reactions, unconcern how they are perceived and valued, increases insensitivity and indifference to others, decreases empathy, which disturbs good interrelations, the start of emotional relations and their preservation. Besides, consistent keeping of one's own opinion, exceptional orientation to internal information and to internal standards lessen flexibility and adaptivity in working relations. Therefore, self-isolation or rejection of others is very probable (Robin, 1994).

As it is known, every action is stimulated by one or even a few motives, and all the more - by a constant and almost turned into a habit, behavioural strategy. Thus, it is worth to consider, what motivation could be related with different self-monitoring levels. In this case, it could be possible to hypothetically interpret controversies, referring to character orientations, described by philosophy and psychology classic Erich Fromm (1976). The author distinguished productive character orientations, which are directed to self, to personality's being, to self- improvement and to self-education need; and non-productive character orientations, which are directed to environment, and are realised seeking to satisfy the need to get and have. Behavioural strategies of people orienting to non-productive values, are rather different. E. Fromm described and named them as follows: receiving, taking through force, hoarding and marketing. Namely, people following marketing value orientation have high selfmonitoring level, because they present themselves to others in the way the environment "requires". In other words, they adjust their behaviour, attitude, etc. to social expectations and to social situations. In order to achieve this, they undoubtedly have to sensitively react to other people's reactions.

Behavioural strategies of low self-monitoring people can be related with the productive character orientations, because in fact, they tend to follow internal representations and are concentrated more to self than to environment. However, it is not difficult to understand, that strong individualism and isolation from social expectations disturb self-creation and self-education processes. Despite the fact, how high we value the personality's authenticity, nevertheless, the determinant and the reference point of personality's power and ability development is society. Thus, seeking to realize optimal self-monitoring level, we have with deep awareness and argumentatively give answers to the questions, what we want from ourselves and from life: to be and improve or to get and have? However, even giving the priority to life fullness, a necessity remains to solve a dilemma of the relationship between self and the others.

\section{References}

Baron, R. A., Greenberg, J. (1990). Behavior in organizations. 3rd Ed. Boston, MA: Allyn \& Bacon. Fromm, E. (1976). To have or to be? Continuum, New York.

Robin, S. H. and others (1994). Self-monitoring of Attention versus Self-Monitoring of Performance: Replication and Cross-Task Comparison Studies. Learning Disability Quarterly, 17 (2), 121-139.

Snyder, M. (1974). Self-monitoring scale. Internet access:

http://www.cabrillo.edu/ jtice/Psychology\%2033/Assignments/Journal\%20Assignment\%20Spring\%202010/ Self\%20Monitoring\%20Scale.PDF

Snyder, M. (1974). Self-monitoring of Expressive Behaviour. Journal of Personality and Social Psychology, 30, 526-537.

Received: May 25, 2012

Accepted: June 22, 2012

Irena Gailienè $\quad \mathrm{PhD}$, Associate Professor, Member of the Editorial Board of Problems of Psychology in the $21^{\text {st }}$

Century, Siauliai, Lithuania.

E-mail: gailiene@splius.It

Website: http://www.irenagailiene.altervista.org/irena/ 